๑ Entomologica Fennica. 29 December 2003

\title{
Life history and description of the preimaginal stages of Scythris siccella (Zeller, 1839) (Lepidoptera: Scythrididae)
}

\author{
Tomasz Baran
}

\begin{abstract}
Baran, T. 2003: Life history and description of the preimaginal stages of Scythris siccella (Zeller, 1839) (Lepidoptera: Scythrididae). — Entomol. Fennica 14: 211-219.
\end{abstract}

Egg, second, and last instar larvae, as well as pupa of Scythris siccella (Zeller, 1839) are described and illustrated in detail. Life history of this scythridid species is also presented. The eggs are laid singly or in small groups. The larva mines leaves of Hieracium pilosella and Rumex acetosella; it lives in sandcovered silken tubes attached to food plant. The full-grown larva is $8-10 \mathrm{~mm}$ long, and pupation takes place in a dense cocoon encrusted with grains of sand. The adults fly in one generation, from the end of May to the end of July. In Poland, Scythris siccella (Zeller) inhabits open, lowland dunes with xerothermic vegetation.

Tomasz Baran, Institute of Biology and Environmental Protection, University of Rzeszów, Rejtana 16C, 35-310 Rzeszów, Poland; E-mail: tbaran@univ.rzeszow.pl

Received 23 October 2002, accepted 24 January 2003

\section{Introduction}

Scythris siccella (Zeller, 1839) belongs to the siccella-species group (Bengtsson 1997), which comprises small moths with dark forewings covered with some paler scales. Besides S. siccella, this group includes three other species: $S$. lafauryi Passerin d'Entreves, 1986, S. lempkei Bengtsson \& Longhorand, 1989, and S. subsiccella Bengtsson, 1997 (Bengtsson 1997). All these scythridids are similar externally so they are comparatively difficult to distinguish on the basis of superficial characters. Only S. siccella is known in many regions of Europe but it occurs locally, especially in the northern part of the continent. In the literature there is little information on life history and morphology of immature stages of this species. Moreover, some information needs to be verified, because $S$. siccella has often been confused with a few similar species in the past. Only brief descriptions of the larva have been published by Spuler (1910) and Meyrick (1928). In all above-mentioned publications as well as in Emmet (1988), some information on host plants and phenology of the species is also given. The pupa was described by Patočka (1997) but his description was based on one female pupal shell only. The egg stage hitherto remained unknown. For all these reasons, I began a comprehensive investigation on this species a few years ego. The aim of the study was to fill a gap in knowledge on the life history and morphology of S. siccella. In this article all preimaginal stages of this scythridid are described in detail, and results of my observations on the life history of the species are also presented. 


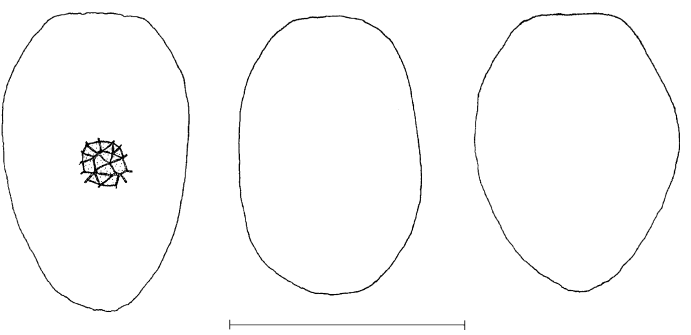

Fig. 1. Forms of egg shell (scale bar $0.5 \mathrm{~mm}$ ).

\section{Materials and methods}

The material was collected and biological observations were made at two sites in central Poland: Toruń and Glinki near Torun (both in one square of UTM grid system - CD37). The sites were open inland dunes with Armeria elongata, Artemisia campestris, Calluna vulgaris, Carex ericetorum, Convolvulus arvensis, Dianthus carthusianorum, Festuca trachyphylla, Hieracium pilosella, Jasione montana, Koeleria glauca, Rumex acetosella, Senecio vernalis, Spergula vernalis, Thymus serpyllum, and some young pine trees.

For morphological study 20 eggs, 30 larvae, and 12 pupae of Scythris siccella were examined. Larvae and pupae were obtained by rearing and collecting in the field, whereas eggs were obtained only by rearing of females. In the course of comparative studies, larvae of Areniscythris brachypteris Powell, 1976 were also examined (JAP 77M4; ESSIG Museum of Entomology, University of California, Berkeley, USA). Caterpillars were macerated in $10 \% \mathrm{KOH}$ prior to the study of chaetotaxy.

Terms used for morphological structures follow: Baran (1999), Fehrenbach (1995), Hasenfuss (1980), Hinton (1946), and Patočka (1997).

\section{Results}

\subsection{Morphology}

\subsubsection{Egg}

Length 0.53-0.60 mm; width 0.37-0.42 mm. Egg shell barrel-shaped, widened about the middle of its length. Upper pole flattened, lower pole more or less pointed or rounded (Fig. 1). Micropylar plate more or less round (diameter: 7.7-8.4 $\mu \mathrm{m}$ ), surrounded by $4-6$ cells arranged in a rosette; the cells of the rosette distinctly bigger than the micropylar plate (Fig. 2). Chorion covered with a network of ribs forming triangular or tetragonal cells.
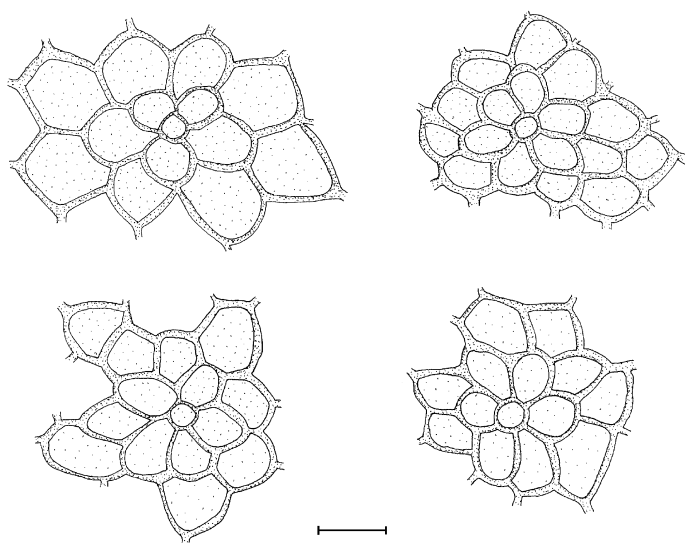

Fig. 2. Micropylar region of egg - examples (scale bar $0.02 \mathrm{~mm}$ ).

Egg lemon-yellow on laying; then turning yellowish; just before hatching of young larva becoming dirty yellow.

\subsubsection{Second instar larva}

Body pattern: length of larva $2.8-3.5 \mathrm{~mm}$; head capsule width $0.26-0.27 \mathrm{~mm}$. Head dirty yellow-brown, darker laterally; ocellar areas blackish. Prothoracic shield dirty yellow-brown in anterior part and darker posteriorly; dorsal line narrow, whitish. Dorsal side of 2nd and 3rd thoracic segments cream-white in anterior and posterior parts, and purple-brown in middle ones. Last two thoracic segments with sometimes broken whitish dorsal line. Dorsal side of abdominal segments 1-8 purple-brown in two-thirds of their length; remaining parts of these segments whitish; 9th abdominal segment purple-brown, and 10th one whitish. Anal shield dirty yellow-brown, well sclerotized. Ventral surface of body orangebrown. Prothoracic legs white with visible sclerites coloured like anal shield.

Chaetotaxy (Fig. 3a): thorax. Segment 1: XD1, XD2 and SD1 almost in a line, but SD1 somewhat posterior. D1dorso-anterior to D2. L1, L2, L3 almost in a horizontal line. SV group with SV1 and SV2 setae. V1 close to coxa. Segments 2-3: D, SD groups and L1, L2 setae in an oblique line. L3 postero-dorsal to L1 and L2. SV group with one seta - SV1. V1 close to coxa.

Abdomen. Segment 1: D2 posterior and slightly ventral to D1. Minute seta SD2 adjacent 
to anterior part of basal ring of SD1, its position somewhat variable. Apodeme of SD group visible. L2 close to L1. SV group with three setae SV1, SV2, SV3 (SV3 anterior to SV1, and SV2 postero-ventral to SV1. V1 ventral to SV group. Segment 2: arrangement of setae the same as on 1 st abdominal segment, but D1 more remote from MD1, MV3 placed closer to SV group, and SD group less remote from spiracle. Segments 3-6: arrangement of D, SD, L groups similar to this of previous segment. SV group with SV1, SV2, and SV3 (all setae almost in a oblique line). MV3 near to SV group. Segment 7: arrangement of $\mathrm{D}, \mathrm{SD}$, $\mathrm{L}$ groups similar to this of abdominal segments 3-6. SV group with SV1 and SV3 (SV3 anterior or antero-ventral to SV1). Segment 8: D2 posterodorsal to D1. SD group without apodeme. Pinaculum of SD group (extra ring) as an elongate sclerite; posterior part of the pinaculum directed ventrally. Very small SD2 seta adjacent to basal ring of SD1. L3, SV group and V1 almost in a vertical line. SV3 antero-ventral to SV1. Segment 9: D2 dorsal to D1. SD1 below D2. L3, SV1 and V1 almost in a vertical line. Segment 10: anal shield with D1, D2, D3 and SD1 setae. Between AL2 and AV4 there is an additional subprimary seta. AV2 and AV3 placed more laterally than AV1 and AV4.

Almost all tactile setae have a modified apex which is slightly dilated with a saw-toothed rim surrounding an apical, pointed cone (Figs. $3 \mathrm{~b}$ and 4). Moreover, these setae are relatively short and stout. Remaining setae on body pointed apically.

Unmodified seta SD1 of abdominal segment 8 longer than SD1 of other abdominal segment. On 9th abdominal segment D2 a few times longer than D1; L1, L2 setae longer than the respective ones of abdominal segment $1-8$. L3 of 8 th and 9th abdominal segments shorter than other abdominal L3 setae. SD1 of 1st abdominal segment somewhat longer than SD1 of abdominal segments 2-7. Pinacula of setae indistinct or absent.

\subsubsection{Last instar larva}

Body pattern (Figs. 5 and $6 a-b)$ ): length of larva 8-10 mm; head capsule width $0.47-0.51 \mathrm{~mm}$. Body markedly elongate and gradually tapered. Segments and head coloured as those of second

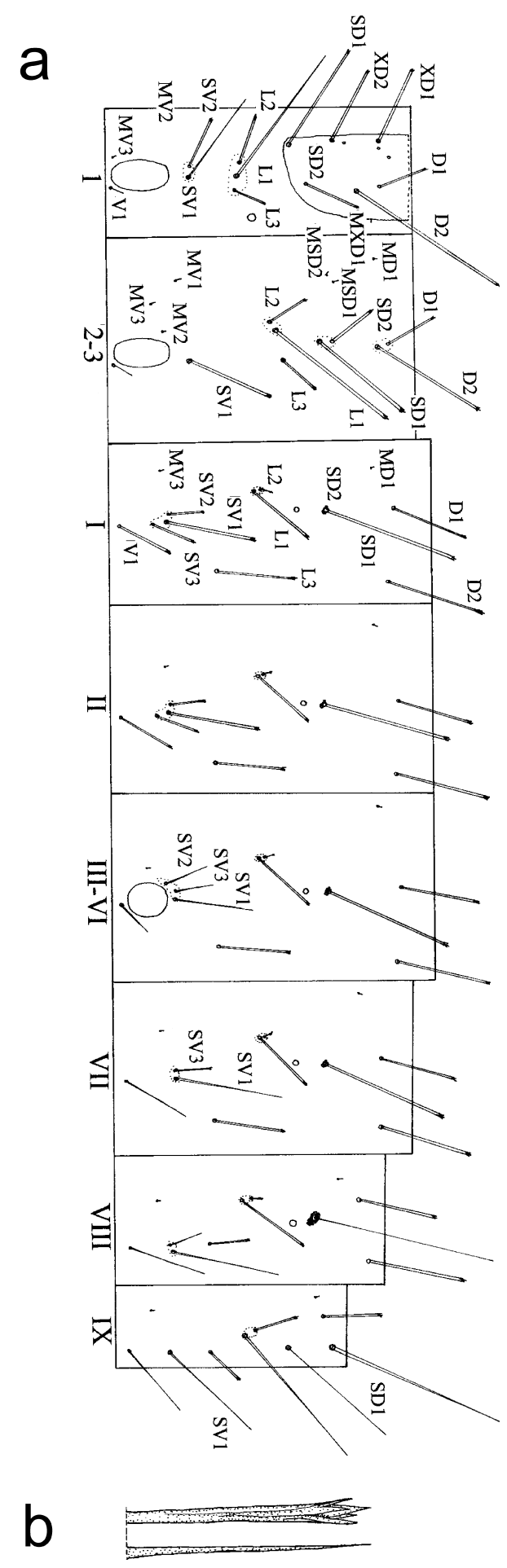

Fig. 3. Setal map of second instar larva. - a. Thoracic (1-3) and abdominal (I-IX) segments. - b. Apices of tactile setae. 


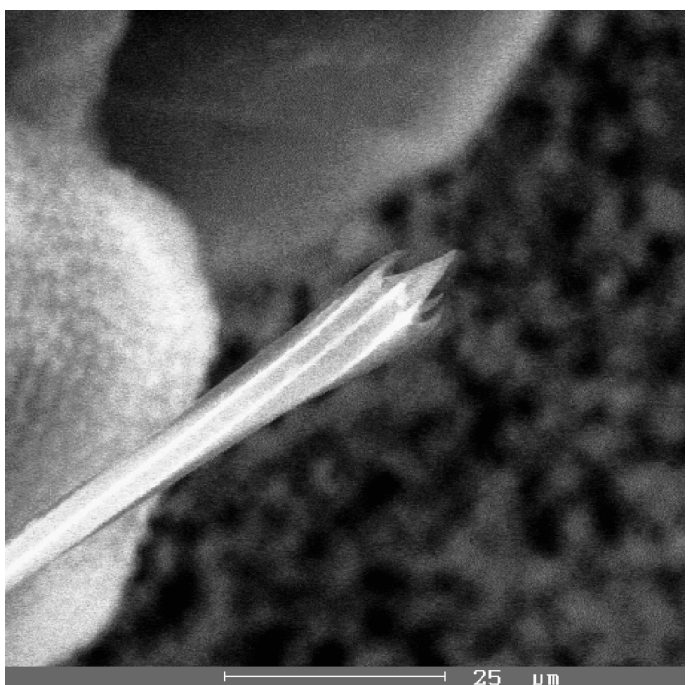

Fig. 4. Apex of tactile seta.

instar larvae, except for: head with whitish, narrow areas next to adfrontals; on 2nd and 3rd thoracic segment, dorsal line in form of spots, indistinct; on most segments, small whitish spots present; pinacula sclerotized, but not contrasting with ground colour.

Chaetotaxy: head capsule (Fig. 6a, c). P1, P2, pore $\mathrm{Pb}$ and seta $\mathrm{AF} 2$ below apex of frons. $\mathrm{P} 2$ latero-posterior to P1. V1, V2, V3 and pore Va almost in a line. Labrum with shallow incision of anterior margin (Fig. 6d-e). Mandible with six teeth, innermost tooth extremely small (Fig. 6f). Thorax (Fig. 7). Segment 1: thoracic shield with several secondary setae located mainly along anterior margin (Fig. 8a). L group with 2-3 secondary setae on common pinaculum. SV1, SV2 and 2-3 secondary setae on elongated pinaculum. V1 without secondary setae. Segment 2. Pinacula of $\mathrm{D}, \mathrm{SD}$ groups, L1 and L2 setae, as well as SV1 with secondary setae, whereas L3 and V1 without them. Abdomen (Fig. 7). Segments 1-2: D1 with 2-4 secondary setae on common pinaculum. D2 with 1 secondary seta. L3 with 1-2 secondary setae on pinaculum. On the segment there is one separate group of secondary setae, placed anteriorly and slightly dorsaly to L3 seta; it consists of 2 setae. $\mathrm{L} 1$ and $\mathrm{L} 2$ on common pinaculum without secondary setae. SV group and V1 with secondary setae. Segments 3-6. Arrangement of setae as on previous abdominal segment, except for: D1 with 2-3 secondary setae; SV group with

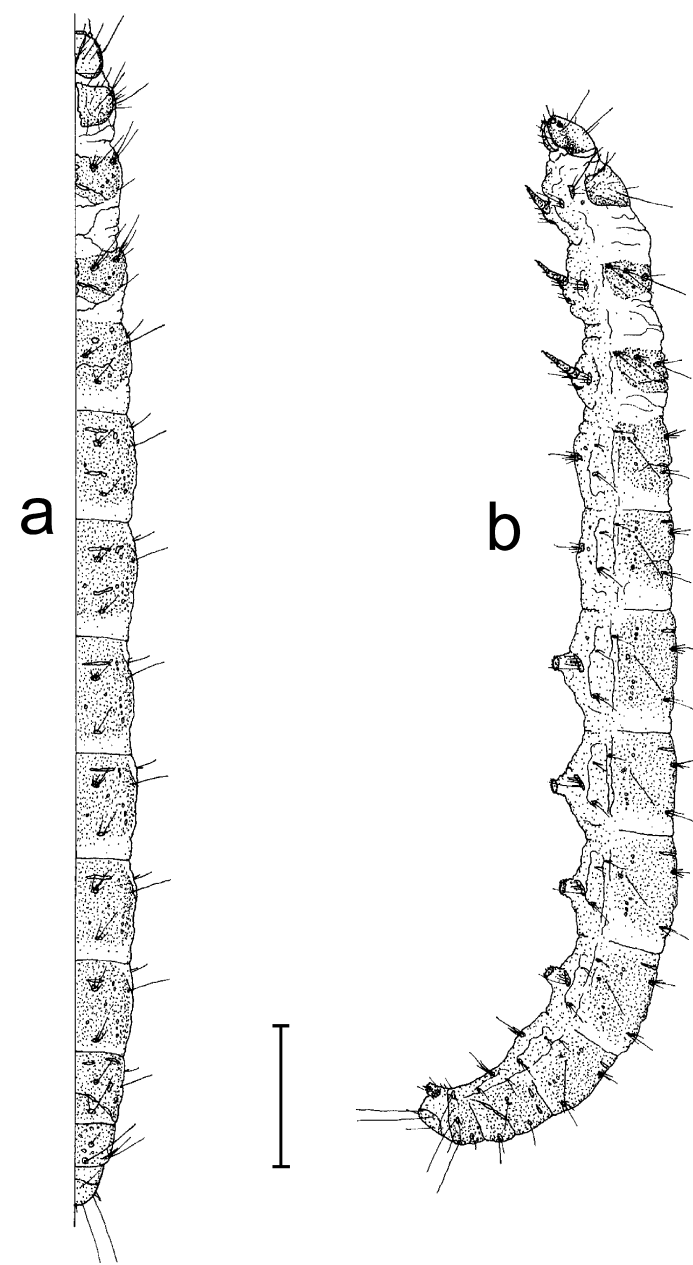

Fig. 5. Mature larva of $S$. siccella (scale bar: $1 \mathrm{~mm}$ ). - a. Dorsal view. - b. Lateral view.

2-3 secondary setae on elongated pinaculum; V1 without additional setae. Segment 7. Arrangement of setae similar to this of 1 st and 2nd abdominal segments, except for: pinacula of D1 and D2 with 1-2 secondary setae; L3 with 1 secondary seta on common pinaculum; SV group with 1 , and V1 with 1-2 secondary setae. Segment 8 . The separate group of secondary setae absent. Pinacula of D1 and L3 without secondary setae. D2 with 1 secondary seta on pinaculum. Arrangement of remaining setal groups and setae similar to that of preceding segment. Segment 9. Pinacula of D1, D2, L3 and V1 setae without secondary setae. L1 and L2 with 1 secondary seta, and SV1 with 1-2 secondary setae. Segment 10 (Figs. 8b and 9). Anal shield without secondary setae. 

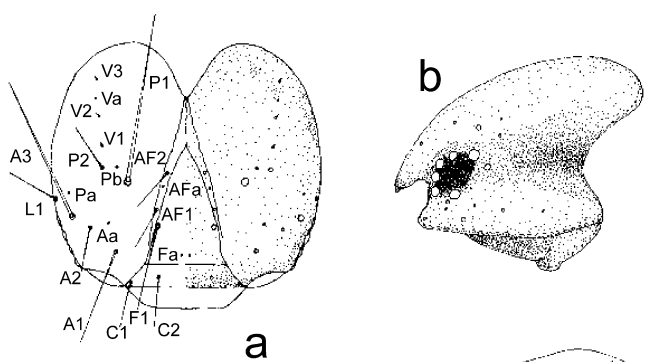

a

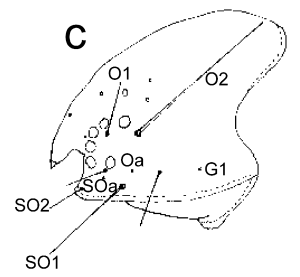

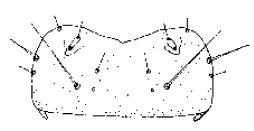

d

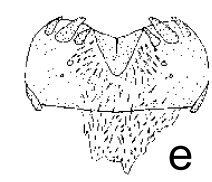

e

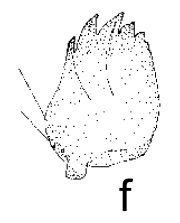

Fig. 6. Head of last instar larva. - a. Frontal view. b-c. Lateral view (scale bar $0.5 \mathrm{~mm}$ ). - d. Labrum (dorsal view). - e. Labrum (ventral view). - f. Mandible (scale bar $0.1 \mathrm{~mm}$ ).

On abdominal segments 1-7, apodemes of SD1 setae well developed, directed somewhat ventrally (Fig. 10a). Pinaculum of SD group of 8th abdominal segment similar to that of second instar larva (Fig. 10b). SD1 of 9th abdominal segment hair-like (diameter of basal ring bigger than diameter of basal part of SD1 seta) (Fig. 10c). Almost all long setae with modified apex (Fig. 4). Crochets of ventral prolegs in biordinal circles (uniordinal in outer parts). Crochets of anal prolegs biordinal in median parts, and uniordinal in lateral parts (Fig. 9).

\subsubsection{Pupa (Fig. 11)}

Length 4.3-5.1 mm; width 1.1-1.4 mm. Frontoclypeal suture distinct. Labrum with shallow incision. Maxillary palpus invisible. Basal part of labial palpi weakly indicated. Proboscis extended to apex of forewing or ending somewhat before. Antenna extended beyond half of proboscis; distance between apex of antennae and apex of

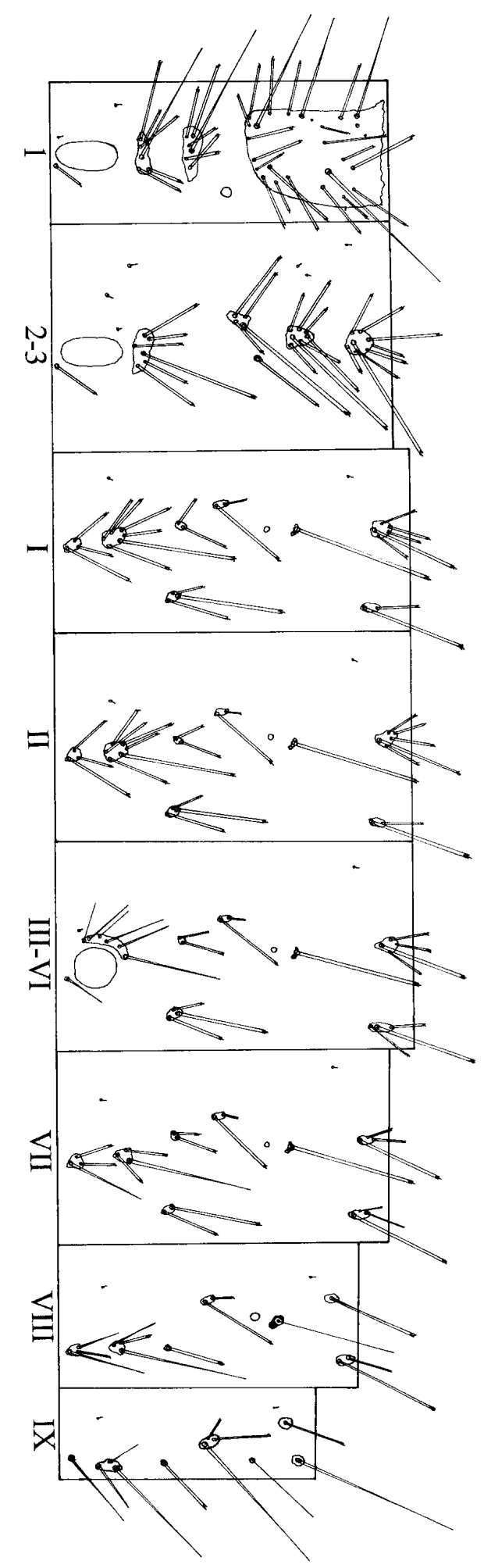

Fig. 7. Setal map of last instar larva. 

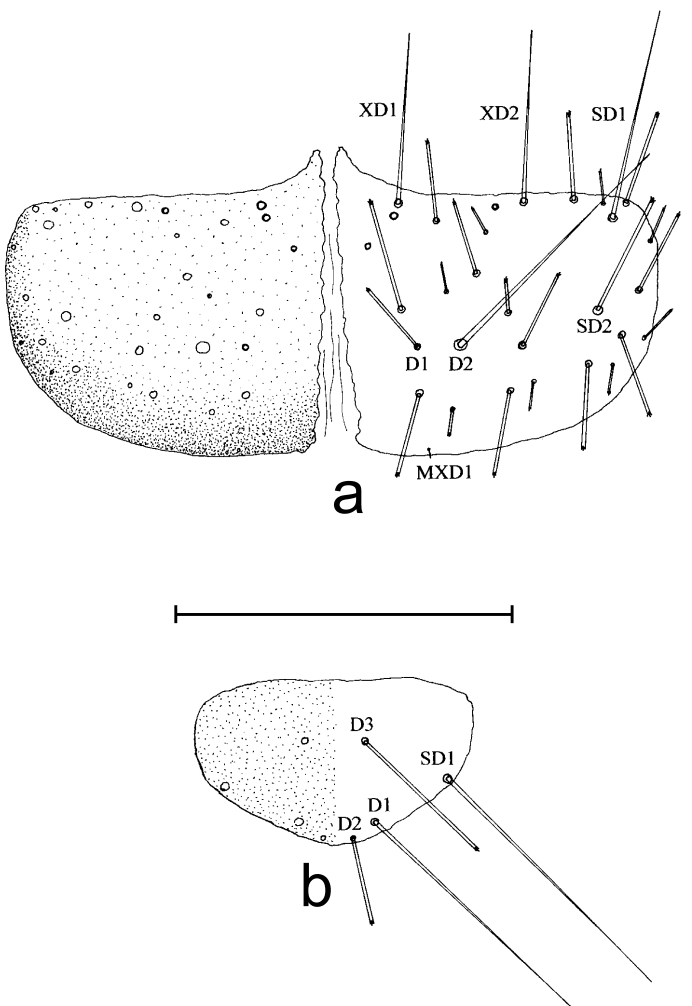

Fig. 8. Larval shields (scale bar $0.5 \mathrm{~mm}$ ). - a. Thoracic plate. - b. Anal plate.

forewing distinctly longer than labial palpi. Midleg extended to about half of proboscis; foreleg somewhat shorter. Hindwing extended to 2nd abdominal segment. Abdominal spiracles protruding. Pupa sexually dimorphic; last abdominal segment of female with a concavity at apex, while that of male is more or less rounded.

\subsection{Life history}

S. sicella lays eggs singly or in small batches of 2-3 eggs. In laboratory conditions, development of this stage takes 9-10 days. Caterpillars are leaf miners throughout their life. In the study areas, larvae mined Hieracium pilosella and Rumex acetosella. However, the former was the main food plant in the studied habitats, while the latter was only a facultative one because only a few caterpillars were found on Rumex acetosella. Larvae live solitarily in silken tubes covered with grains of sand (Fig. 12). Frequently, a few tubes

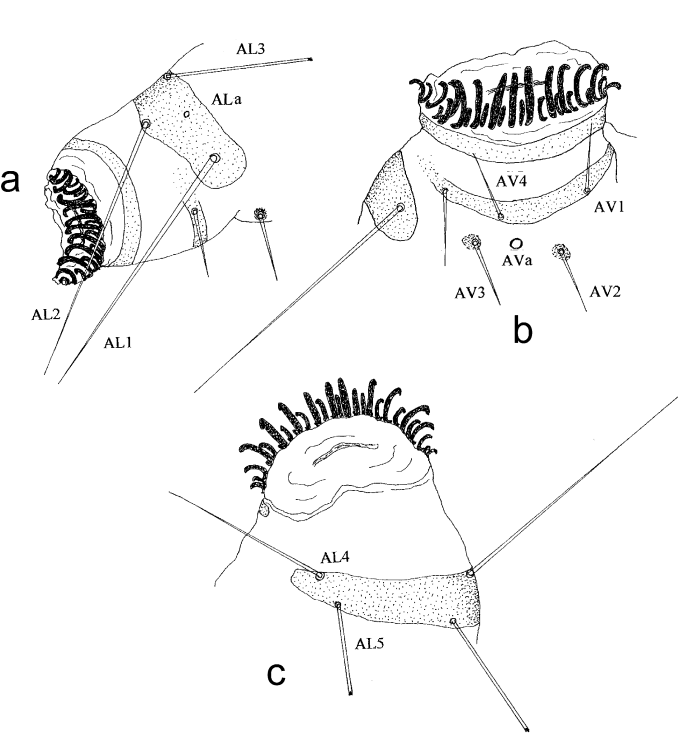

Fig. 9. Anal proleg (scale bar $0.3 \mathrm{~mm}$ ). - a. Lateral view. - b. Ventral view. - c. Dorsal view.

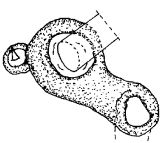

a

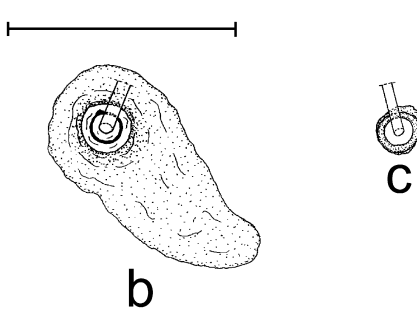

Fig. 10. Abdominal SD groups of mature larva (scale bar: $0.05 \mathrm{~mm}$ ). - a. Segments $1-7 .-$ b. Segment 8 . - c. Segment 9.

with caterpillars were observed on a single plant. Tubes are attached to the underside of leaves and they attain about $1.5-2.5 \mathrm{~cm}$ in length. During its development, the larva makes an irregular, blotchlike, pale brownish mine (Fig. 13) which may occupy an entire leaf blade; during feeding, the larva can change leaves. In the field, mines are relatively easy to discover because of the discoloration of the leaves, and the fact that they are visible on the upper surfaces of leaves. Larval tubes are attached to leaves that are in contact with sandy ground in most cases so that they are not noticeable without raising a leaf. The best way to find larva of S. siccella is by searching for brown spots on the leaves of the food plants. 


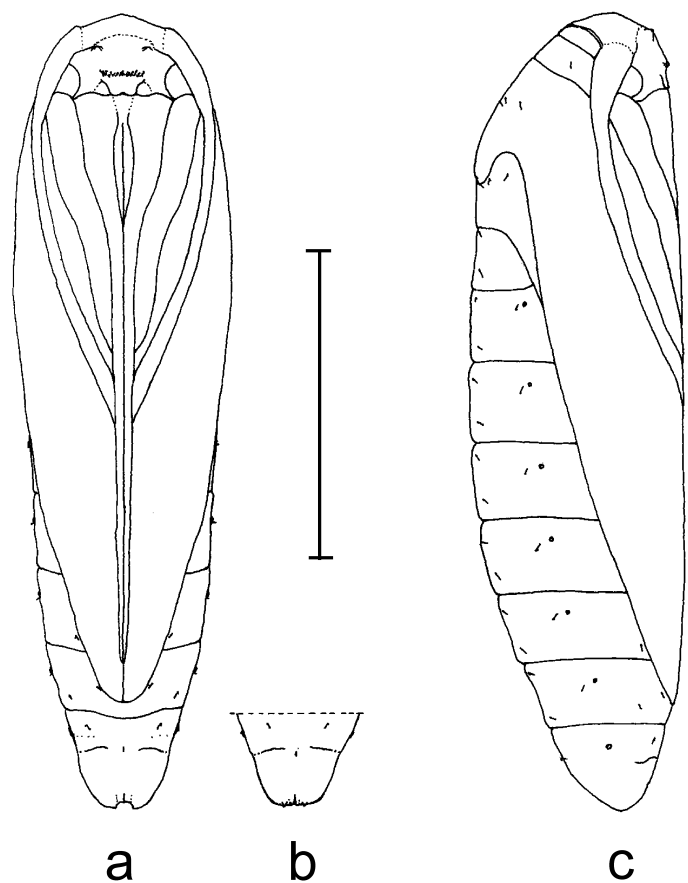

Fig. 11. Pupa of $S$. siccella (scale bar $2 \mathrm{~mm}$ ). - a. Ventral view of female. $-b$. Ventral view of male $(a$ fragment). - c. Lateral view of female.

Larvae go through five instars during their development. In nature, they start mining during the first half of April and can be found to the end of June. Pupation takes place in a dense cocoon encrusted with grains of sand, and sometimes with various fragments of plants as well. Most often, larvae pupate near their host plant on the ground or just beneath the sand surface. In captivity, the pupal stage lasts 10-12 days. Adults are univoltine and occur during a rather long period, from the end of May to the last days of July. In sunny days, moths were observed on the flowers of various plants: Convolvulus arvensis, Senecio vernalis and Jasione montana. In Poland, this thermophilic species is associated strictly with xerothermic grassland on sandy soil; it is rare but where it occurs, it is usually abundant. In the investigated areas, $S$. siccella may coexist also with other Scythrididae, such as S. bifissella (Hofmann, 1889), S. cicadella (Zeller, 1839), S. clavella (Zeller, 1855), and S. potentillella (Zeller, 1846).

On the basis of field observation and outdoor rearing, S. siccella hibernates as a young larva. This assumption is supported by three facts.

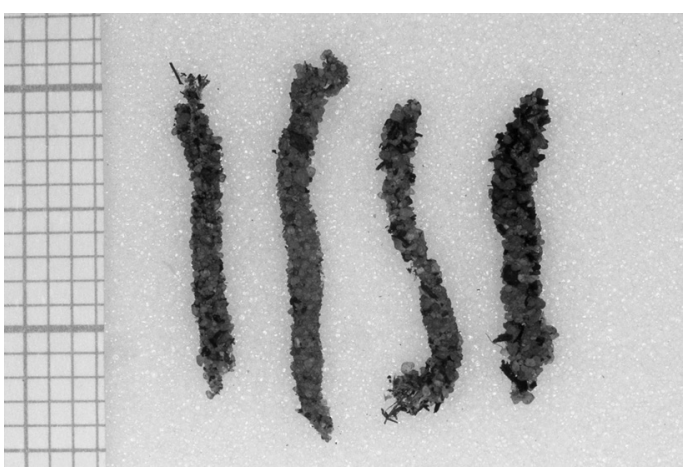

Fig. 12. Tubes of mature larvae of $S$. siccella.

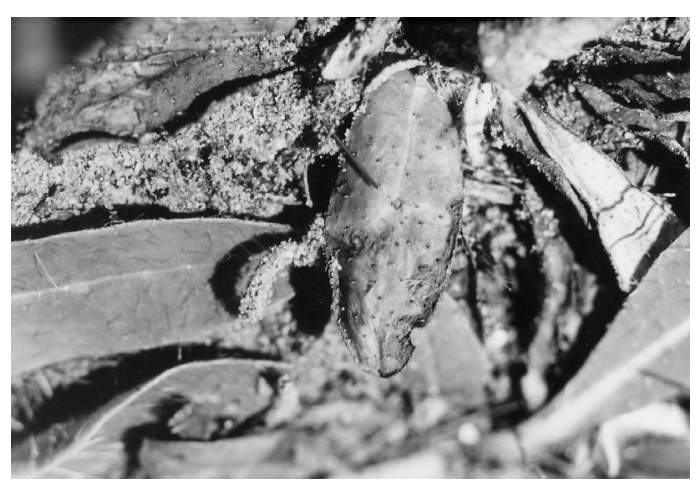

Fig. 13. Larval tuba and mine of $S$. siccella on Hieracium pilosella.

Firstly, no caterpillars have been found in the period between the end of imago occurrence (July) and winter; secondly, larvae always hatched before winter in outdoor rearing; thirdly, young (second instar) mining larvae were observed in early spring. Most probably, newly hatched larvae enter summer diapause and, depending on weather conditions, they may begin feeding before hibernation.

\section{Discussion}

The knowledge about preimaginal stages of Scythrididae is rudimentary. Thus, results presented in this paper can be compared with morphological and biological details of few other members of the family.

Structure of chorion ribs of the studied species is similar to that of S. clavella (Baran 1999) 
and S. bifissella (Baran 2002). Eggs of these scythridids can be distinguished by the size of micropylar plate: the plate of $S$. siccella is smaller than that of S. bifissella $(8.8-14 \mu \mathrm{m})$, and larger than the plate of S. clavella $(6.8-7.1 \mu \mathrm{m})$.

The highly modified body form of the larval stage of S. siccella (slender and elongate with a small head) is the result of adaptation for life in specialized habitats such as sand dunes, as well as for the mining manner of feeding. Such larval shape is often characteristic of sand-dune-dwelling insects (Powell 1976). Within Scythrididae, extraordinarily elongate larvae previously were discovered in the endemic Nearctic genus Areniscythris, species of which inhabit active sand dunes of southwestern Canada and the western parts of the Unites States (Landry 1991). The only known caterpillars of this genus are those of Areniscythris brachypteris Powell, 1976. They skeletonize green parts of their food plants from sand-covered silken tubes similar to those of S. siccella (Powell 1976, Landry 1991), and these life habits have been regarded as a probable apomorphic feature of the genus by Landry (op. cit.).

With reference to larval chaetotaxy, S. siccella possesses a few very interesting and perhaps phylogenetically important features. As this study disclosed, it has some tactile setae with unusual modified apices. Unexpectedly, similarly modified setae were found also in A. brachypteris (T. Baran unpubl.). However, at present it cannot be said whether this similarity (as well as resembling life habits) is indicative of relationships between these scythridids or it is the result of convergent evolution. A likely synapomorphy for members of the siccella-species group may be the position and shape of pinaculum of SD group on 8th abdominal segment; the sclerite of S. siccella is elongated postero-ventraly, whereas in other described larvae of Scythrididae it is elongated distinctly posteriorly (Baran 1999, 2002, MacKay 1972). Moreover, SD group of 1st-7th abdominal segments lacks extra rings (pinacula). Such rings are present in all other known Scythrididae larvae, and the only known case of their reduction is in the larva of Areniscythis brachypteris (Powell 1976). This character may have some significance in research on phylogeny within the family, but this feature involves a simple loss, thus it provides weak evidence for phylogenetic relation- ships. The larva of $S$. siccella has one separate group of secondary setae on abdominal segments 1-7 situated anteriorly and slightly dorsally to pinaculum of L3 seta. This character is very stable (it was observed in all studied larvae of the family) and unique within Lepidoptera. Thus, besides autapomorphic features given by Landry (1991), it may represent additional evidence for the monophyly of the family Scythrididae, if it is also found in other species of Scythrididae (T. Baran in prep.).

With respect to biological data, the leaf-mining habits of larvae and food plant selection of the species are worth noticing. Mining caterpillars are uncommon within Scythrididae, because such a way of feeding has been confirmed by rearing only in the Nearctic genus Asymmetrura (Landry 1991). So far S. siccella is the only welldocumented case of mining scythridid in the Palearctic region. As for food plant preference, the species is probably polyphagous, and it feeds on suitable plants within its habitats. Though larvae of the studied species were found only on two plants (one of them was clearly preferred), $S$. siccella accepts a wide range of host species, if other published host records are also taken into account. Scythris siccella have been recorded on the following host plants: Helichrysum sp., Rumex acetosa (for S. variella Stph.; Spuler [1910]), Cerastium, Lotus, Thymus, Plantago (Meyrick 1928), Helianthemum sp. Hieracium sp., Ononis sp., Scabiosa columbaria (for $S$. variella Stph.; Schütze [1931]), moreover, Thymus drucei and Lotus corniculatus (Emmet 1988). It should be stressed, however, that at least some of these records need to be confirmed. Especially unreliable are those given for $S$. variella, because they may concern also other scythridids. Nevertheless, the ability of larvae to develop on various plants without narrow host specialization would represent a survival strategy of S. siccella that inhabits habitats with highly variable biotic factors.

There is a certain similarity in morphology and biology between larvae of S. siccella (siccellaspecies group?) and those of the Areniscythris complex (sensu Landry 1991), which could indicate an affinity between these taxa. However, leafmining habits of the larvae are a feature observed in the Nearctic genus Asymmetrura, but not in Areniscythris. 
Acknowledgements. I am very grateful to Professor Jerry A. Powell (University of California, Berkeley, USA) for the loan of valuable larval material, as well as to an anonymous referee for constructive criticism that improved the first version of this paper.

\section{References}

Baran, T. 1999: Morphology and biology of Scythris clavella (Zeller, 1855) (Lepidoptera: Scythrididae). — Pol. Pismo Ent. 68: 165-195.

Baran, T. 2002: The immature stages and bionomics of Scythris bifissella (Hofmann, 1889) (Lepidoptera: Scythrididae). — Pol. Pismo Ent. 71: 195-209.

Bengtsson, B. A. 1997: Scythrididae. — In: Huemer, P., Karsholt, O. \& Lyneborg, L. (eds.), Microlepidoptera of Europe 2: 1-301.

Emmet, A. M. 1988: A Field Guide to the Smaller British Lepidoptera. — British Entomology \& Natural History Society, London. 271 pp.

Fehrenbach, H. 1995: Egg shell of Lepidoptera - fine structure and phylogenetic implications. - Zool. Anz. 234: $19-41$.
Hasenfuss, I. 1980: Die Präimaginalstadien von Thyris fenestrella Scopoli (Thyrididae, Lepdoptera). - Bonn. Zool. Beitr. 31: 168-190.

Hinton, H. E. 1946: On the homology and nomenclature of the setae of lepidopterous larvae with some notes on the phylogeny of the Lepidoptera. - Trans. Ent. Soc. Lond. 97: 1-35.

Landry, J.-F. 1991: Systematics of Nearctic Scythrididae (Lepidoptera: Gelechioidea): phylogeny and classification of supraspecific taxa, with a review of described species. - Memoirs of the Entomological Society of Canada 160: 1-341.

MacKay, M. R. 1972: Larval sketches of some Microlepidoptera, chiefly North America. - Memoirs of the Entomological Society of Canada 8: 1-83.

Meyrick, E. 1928: A revised Handbook of British Lepidoptera. - Watkins and Doncaster, London. 914 pp.

Patočka, J. 1997: Die Puppen einiger mitteleuropäischen und kanarischen Scythrididae (Lepidoptera), Gelechioidea). — Tijdschrift vor Entomologie 140: 207-220.

Powell, J. A. 1976: A Remarkable New Genus of Brachypterous Moth from Coastal Sand Dunes in California (Lepidoptera: Gelechioidea, Scythrididae). - Annals of the Entomological Society of America 69: 325-339.

Spuler A. 1910: Die Schmetterlinge Europas 2. - E. Schweizerbart'sche Verlarsbuchhandlung, Stuttgart. 523 pp. 